\title{
Patterns of development of advanced clonal apple rootstocks of the Michurinsk State Agrarian University selection in the mother plantation
}

\author{
Maxim L. Dubrovsky ${ }^{1,}$, Andrey $V$. Kruzhkov $^{1}$, Nataliya L. Churikova ${ }^{1}$, Roman V. \\ Papikhin $^{2}$, and Galina $S$. Usova ${ }^{1}$ \\ ${ }^{1}$ Michurinsk State Agrarian University, Laboratory of Breeding Low-vigorous Clonal Rootstocks and \\ Other Fruit Crops, 393760 Michurinsk, Russia \\ ${ }^{2}$ Michurinsk State Agrarian University, Scientific Centre of Biotechnology and Breeding, 393760 \\ Michurinsk, Russia
}

\begin{abstract}
This paper reveals main patterns of development of advanced clonal apple rootstocks of the Michurinsk State Agrarian University selection in the mother plantation. The studied growth and development indicators of shoots, as well as the level of their rooting in 40 genotypes, demonstrate significant heterogeneity of hybrid plants, which is due to their different genetic origin and the associated unequal growth force of parent shrubs. Correlations between the main quantitative morphological characters of parent shrubs of the studied genotypes were revealed. An interrelation of the height of the parent shrub and the area of its leaf surface is noted - on the expectation of 0.71 shoot; for the entire uterine shrub - of 0.45 ; between the output of standard layering from the shrub and the average rooting score (at 0.72 ). Promising clonal rootstocks with high yield indices in the mother plantation have been identified.
\end{abstract}

\section{Introduction}

Dwarf clonal apple rootstocks are important in the modern intensive gardening, they allow you to directionally control the balance of the fruit tree between the growth of crown's vegetative components and fruiting. Trees of dwarf clonal rootstocks form a smaller crown volume with a simultaneous increase in the growth of fruits. This makes it possible to increase the density of trees in the garden, to form low-volume structures of their crowns, and thereby optimize the light regime of the photosynthetic apparatus and obtain high-quality fruits [1$11]$.

Of great scientific and practical importance is the study of new rootstocks on the basic morphological and physiological indicators. Their leaf apparatus plays an important role in the normal course of a number of physiological processes in the mother plantation, primarily photosynthesis and transpiration [1-3, 12].

* Corresponding author: element68@mail.ru 
Michurinsk State Agrarian University is the leading Russian institution in the field of selection of clonal apple rootstocks, where the selection process has been carried out for more than 80 years and new genotypes of the genus Malus Mill. are being created annually, including by the interspecific hybridization. Now the university has created a significant genetic collection and a hybrid fund of dwarf clonal apple rootstocks, which annually contribute in comprehensive comparative studies [1-3, 13-16]. The identified stocks are characterized by the presence of anthocyanins in the tissues and increased resistance to adverse climatic conditions, especially to the damaging temperatures of the winter period $[17,18]$.

The objective of our research was to study the complex of basic biometric indicators of advanced clonal stocks of apple trees of the Michurinsk State Agrarian University selection under conditions of mother plantation.

\section{Materials and methods}

The biological objects of the study were 36 advanced clonal apple rootstocks from 10 hybrid families of the Michurinsk State Agrarian University selection (obtained in 2002-2009). We used 4 clonal apple rootstocks that are standard in Russia, as well as the university breeds, characterized by different growth rates of scion components - super dwarf Paradizka Budagovsky (outside Russia known as B9 - Budagovsky 9) and Malysh Budagovsky, which is dwarf $62-396$ and semi dwarf 54-118.

All clonal stocks are placed according to the scheme $-150 \times 30 \mathrm{~cm}$ in the mother plantation of vertical layers, located in the Michurinsk district of the Tambov region. The climate is temperate continental, the soil is leached chernozem with an increased content of humus. During the growing season, sprinkler irrigation of parent shrubes was carried out. Agrotechnical measures were as standard. Fertilizers were not applied.

Indicators of parent shrubes were measured at the end of August - at the end of their active growth [19]. The leaf area was calculated using the ImageJ computer program for the analysis of scanned images of 20 leaves from the shoot's middle part. The experimental data were processed using the basic methods of variation statistics and analysis of variance [20], calculated and graphically visualized in the Microsoft Office Excel software.

\section{Results and discussion}

Genotypic differences between the minimum and maximum values of each of the analyzed morphological characters were revealed in the parent shrubs of the studied clonal apple rootstocks:

- the average length of one shoot - 2.5 times greater (in the range from $43.3 \mathrm{~cm}$ of the standard dwarf rootstock Malysh Budagovsky to $108.9 \mathrm{~cm}$ of the form 3-4-7);

- the length of internodes on one shoot - 2.1 times higher (from $1.46 \mathrm{~cm}$ of the form 2-9-49 to $3.07 \mathrm{~cm}$ of the form 2-12-10);

- the shoots' angle of deviation from the vertical direction - 4.5 times lower (from $9.7^{\circ}$ of the form 9-1-2 to $43.9^{\circ}$ of the standard super dwarf rootstock B9);

- the leaf blade area - 2.9 times larger (from 7.7 to $22.6 \mathrm{~cm}^{2}$ of forms 4-2-50 and 2-12-34);

- the number of leaves on one shoot - 2.9 times higher (from 20.0 to 57.4 pcs. of forms 9-1-

2 and 3-4-7);

- the leaf surface area of one shoot - 6.1 times larger (from $185.9 \mathrm{~cm}^{2}$ of the rootstock 4-250 to $1129.6 \mathrm{~cm}^{2}$ of the form 2-12-34);

- the leaf surface area of the parent shrub - 7.3 times (from $1718 \mathrm{~cm}^{2}$ of the standard dwarf rootstock B9 to $12,610 \mathrm{~cm}^{2}$ of the form 2-12-15). 
The specific number of leaves per $1 \mathrm{~m}$ of shoots, calculated in order to compare rootstocks of different growth forces, differed by 1.52 times - from 32.5 to 68.3 pcs. in hybrids $2-12-10$ and 2-9-49, respectively. According to the specific leaf surface area per $1 \mathrm{~m}$ of shoot, the variances between the genotypes differed by 8.9 times - from $7007 \mathrm{~cm}^{2}$ of the dwarf rootstock 4-2-50 to $62532 \mathrm{~cm}^{2}$ of the form 2-12-34. A correlation of 0.71 was established between the indicators of the length of shoots of the parent shrub and their leaf surface area, which reached 0.86 in some hybrid families.

Important technological indicators of cultivation of clonal rootstocks in the mother plantation are the geometric dimensions of their parent shrubs: height, ramification intensity and sprawling of shoots.

In terms of the parent shrubs' height, all the studied genotypes are characterized by significant variability determined by both the genotypic factor and the natural and climatic characteristics of a particular season (Fig. 1). Thus, differences between rootstocks in the shrub height in 2019 were less pronounced, which is reflected in the variation curve in the form of absence of local maxima observed earlier in 2018 and 2017. This is due to the prevailing adverse climatic conditions of most of the summer period of 2019. Despite the sprinkler irrigation of the mother plantation, the relative humidity was significantly reduced, and the average temperature, on the contrary, was elevated. In this regard, indicators of parent plants' yield worsened. The shrub height lesser than $60 \mathrm{~cm}$ was noted in the forms 9-1-1, 9$1-2,9-1-3,9-1-4,2-3-14,2-9-49,2-15-2,2-15-15,5-28-11$ in the mother plantation. The highest parent shrubs (over $100 \mathrm{~cm}$ ) were characterized by stocks 3-4-7 and 54-118.

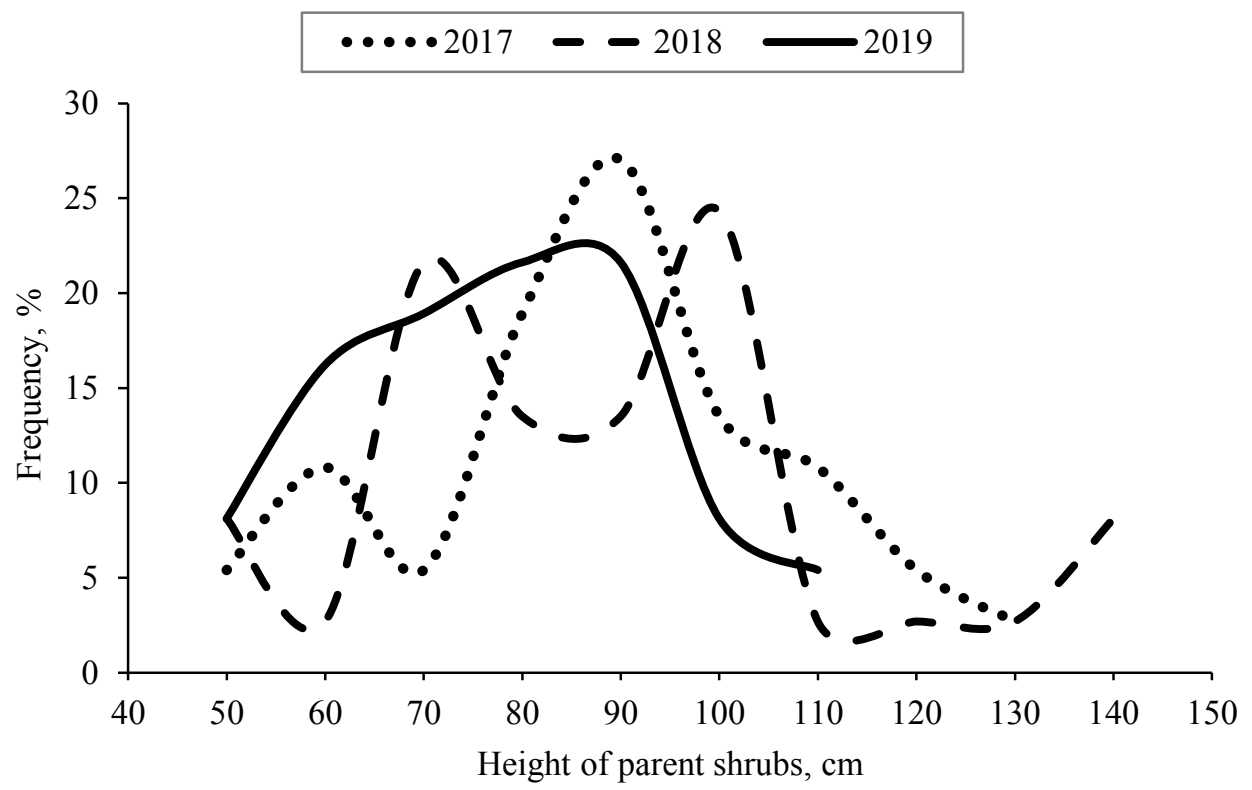

Fig. 1. Variability of average height of parent shrubs in 40 forms of clonal apple rootstocks.

When assessing the quality of layering, the branching of the shoot is taken into account, since this biological feature complicates their cultivation in the nursery and introduces additional costs for the elimination. $91.7 \%$ of the studied stocks were weakly branched. $8.2 \%$ of genotypes are included in the group of medium-branched: 2-12-10, 3-10-3, 5-27-1. Strongly branching stocks are not revealed.

The sprawling intensity of the parent shrubs determines the manufacturability of rootstock cultivation in the mother plantation and the possibility of mechanization of 
individual stages. Forms with upright shoots forming a compact parent shrub are more preferred. For objective analysis of this indicator in plants in the mother plantation, the shoots' angle of deviation from the vertical direction was measured - the lower this indicator is, the more compact is the shrub. The variational curve of the shoots' angle of deviation has three isolated local maximums, which corresponds to the distribution of stocks in the form of parent shrubs into three groups - compact, semi-sprawling, sprawling (Fig. 2). The most upright shoots (deviation from the vertical direction of less than $15^{\circ}$ ) and the most compact parent shrubs noted in the Malysh Budagovsky, 2-3-3, 2-3-17, 2-9-56, 2-9-90, 2-12-10, 212-36, 2-15 -2 , 2-15-15, 4-2-3, 4-2-50, 9-1-2, 9-1-3, 9-1-4, 9-1-5, 9-1-9 rootstocks. The most sprawling parent shrubs with an average shoot deviation from the vertical direction of more than $40^{\circ}$ are distinguished in the B9, 2996, 34-7 rootstocks.

Rootstocks with shorter internodes of the shoots are less convenient for grafting, especially by the T-budding method. Among the 40 genotypes, no significant correlations were found between the internodes length and other characters - the number of leaves per shoot $(-0.44)$ and the parent shrubs height $(0.24)$. The variational curve of the internode lengths is two-modal, with clearly defined maxima in the region of 2.0 and $2.4 \mathrm{~cm}$ (Fig. 3). Rootstocks 54-118, B9, 2-3-17, 2-3-44, 2-12-10, 4-2-3, 4-2-50 have internodes that are over $2.5 \mathrm{~cm}$.

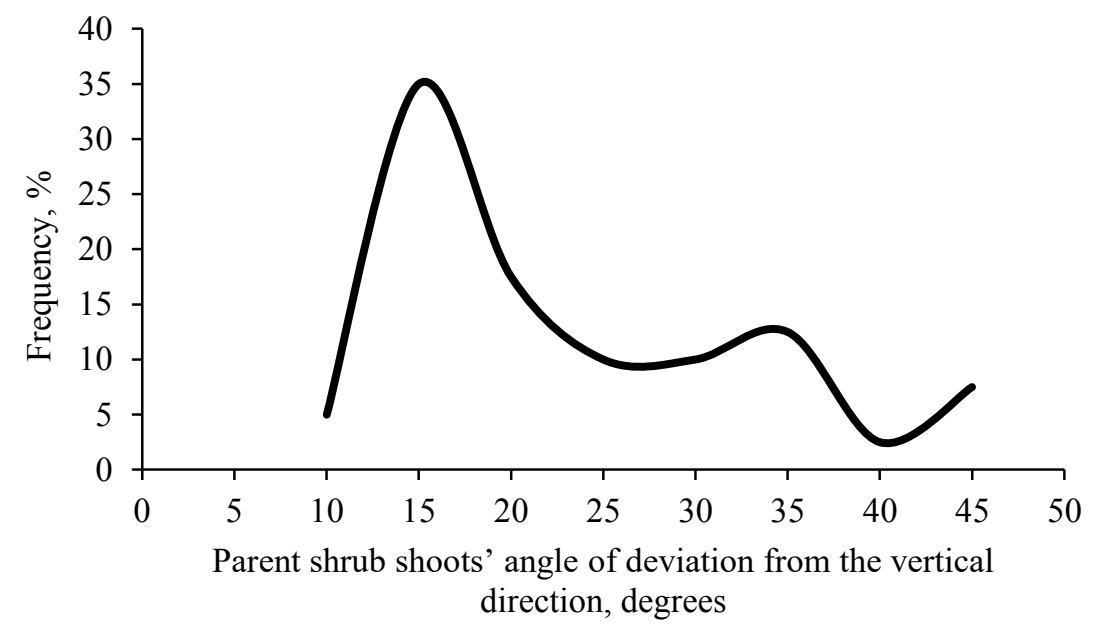

Fig. 2. Variability of angle of deviation from the vertical direction of parent shrub shoots of the clonal apple rootstocks collection. 


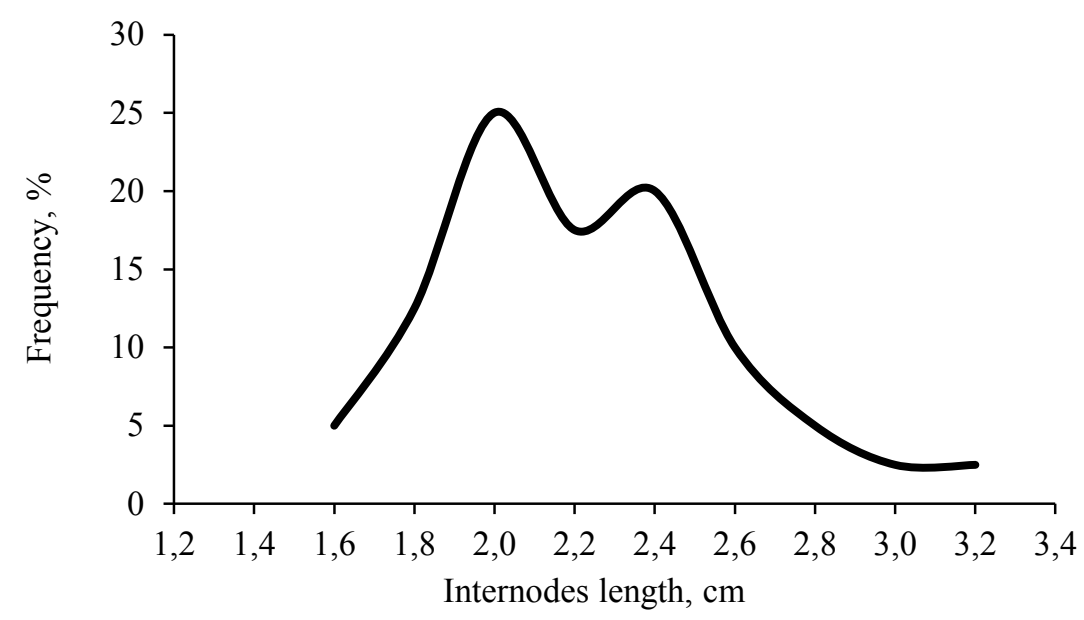

Fig. 3. Variability of internodes length on shoots of clonal apple rootstocks.

It was found that the variation curves of the leaf blade area and the number of leaves on one shoot in the studied clonal rootstocks collection are single-sized and do not have local maxima (Figs. 4, 5). Correlations of the average level between the leaf blade area and the leaf surface size of the whole plant were revealed: per one shoot $(0.68)$ and per parent shrub as a whole (0.48).

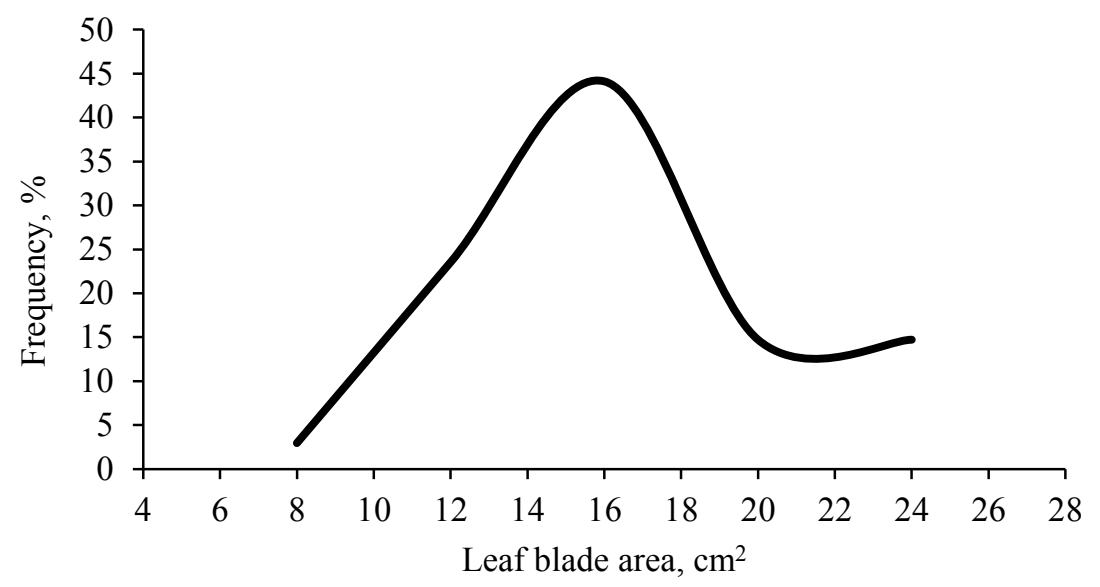

Fig. 4. Variability of the leaf blade area of the clonal apple rootstocks collection. 


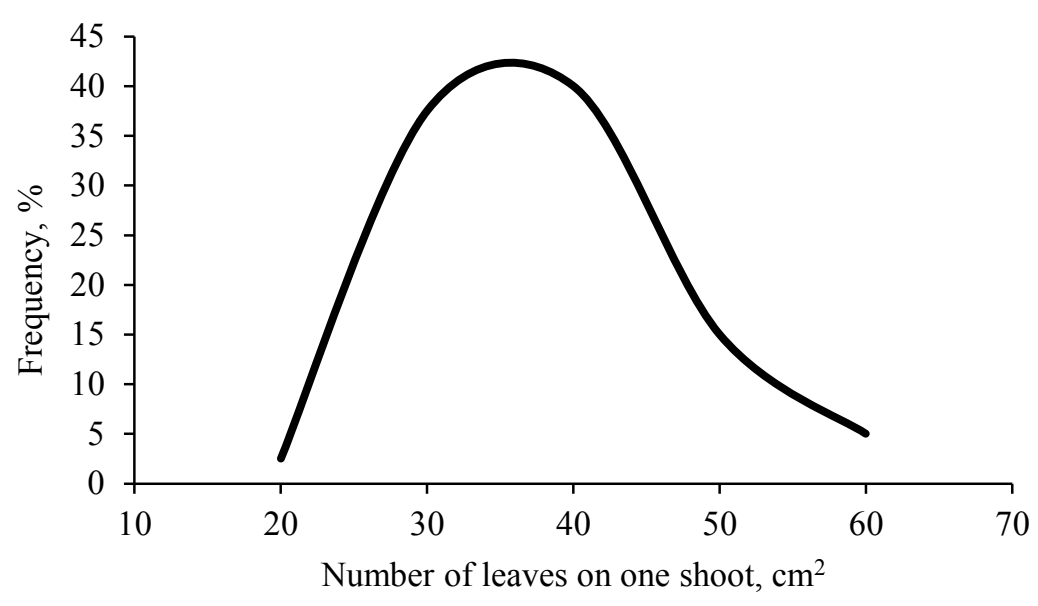

Fig. 5. Variability of the number of leaves on one shoot in the studied clonal apple rootstocks.

Positive correlations were noted between the number of leaves on the shoot and other characters - height of the parent shrubs $(0.76)$; shoot's leaf surface area $(0.71)$; proportion of unrooted layering (0.59); shoots' angle of deviation from the vertical direction (0.48).

The leaf surface area of the parent shrub is characterized by the greatest variability in the studied stocks due to the variability of the initial morphological characters - the shoots length and the number of leaves on them, the average leaf blade area, the number of shoots in the shrub. According to the leaf surface size of the parent shrub, 4 groups of genotypes with intervals of this indicator were clearly distinguished on the variational curve: $2000-5000 \mathrm{~cm}^{2}$, $5000-8000 \mathrm{~cm}^{2}, 8000-11000 \mathrm{~cm}^{2}, 11000-13000 \mathrm{~cm}^{2}$ (Fig. 7). The smallest leaf surface area in the mother plantation (less than $5000 \mathrm{~cm}^{2}$ ) is characterized by the Malysh Budagovsky, B9, 2-3-2, 2-3-3, 2-3-19, 2-9-56, 2-9-90, 2-9-94, 2-12-36, 2-15-2, 2-15-15, 4-2-50, 5-26-127 rootstocks; and the largest (more than $11000 \mathrm{~cm}^{2}$ ) - by 2-12-10 and 2-12-15 forms. A positive correlation of the average level, equal to 0.59 , was established between the leaf surface size of one shoot and the entire plant.

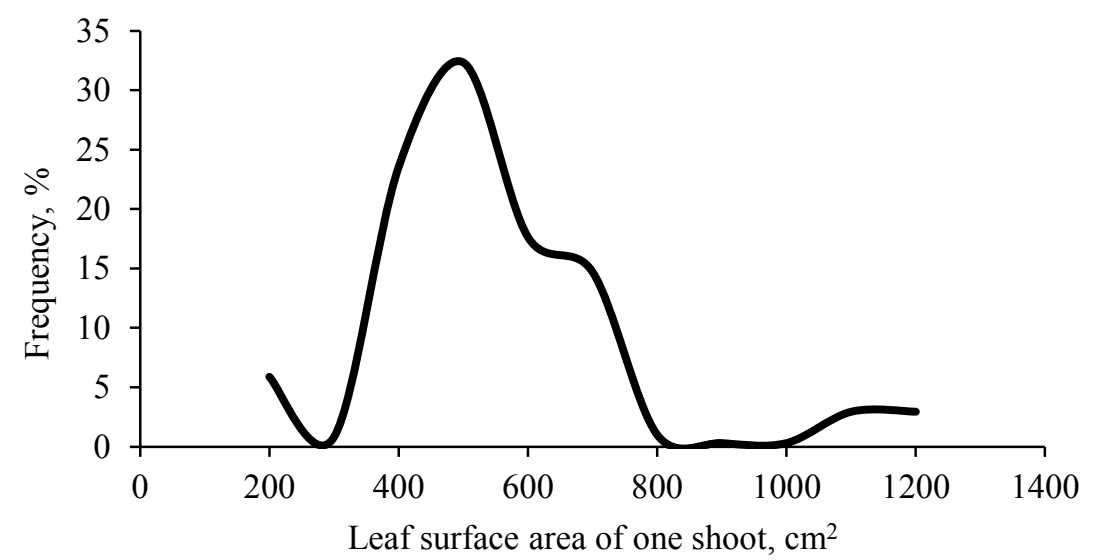

Fig. 6. Variability of the leaf surface area of one shoot of clonal apple rootstocks. 


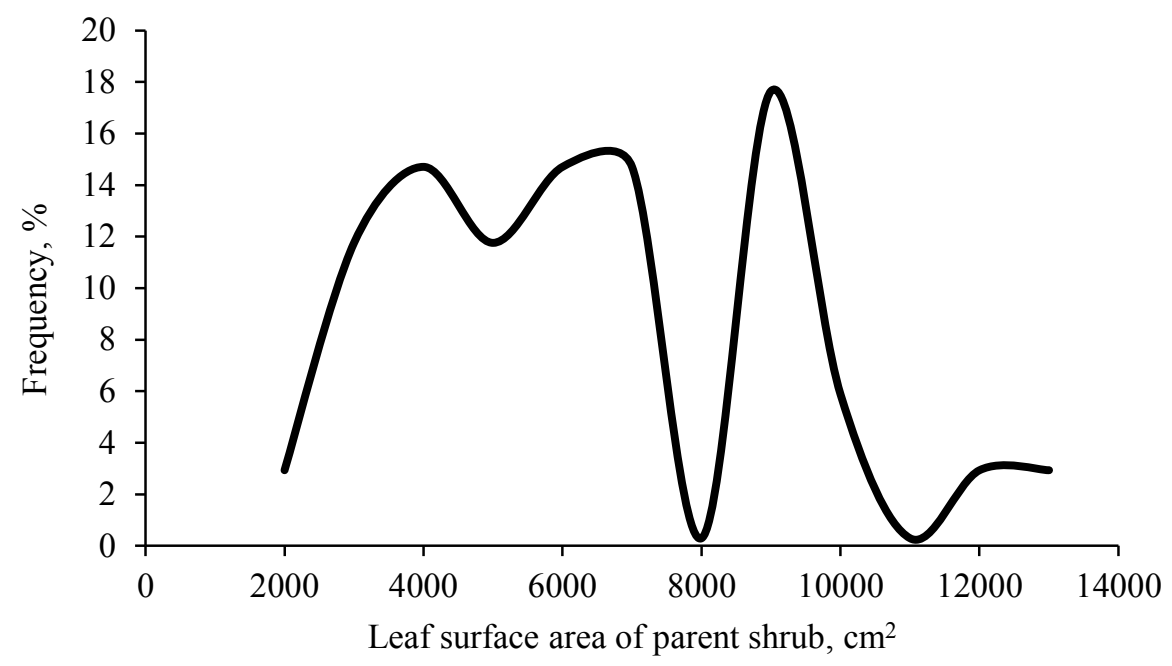

Fig. 7. Variability of the leaf surface area of the parent shrub of clonal apple rootstocks.

Positive correlations among the studied stocks were found between the parent shrub's height and leaf surface area: per one shoot -0.71 ; for the entire parent shrub -0.45 .

The main yield indicators of any rootstock in the mother plantation are the number of the formed rooted layering and the proportion of the standard ones among them. The higher both of these indicators are, the greater is the stock's value for production. A positive correlation was noted at the level of 0.58 between the total number of layering from one shrub and the standard. The interrelation of the unrooted layering ratio with the parent shrubs height $(\mathrm{r}=$ $0.56)$, the number of standard layering in one shrub $(-0.49)$ and their percent yield $(-0.72)$ was established.

The advanced 2-3-14, 2-9-49, 2-9-96, 2-12-10, 2-12-15, 9-1-1, 9-1-4, 9-1-5 forms were characterized by the highest shoot-forming ability of the parent shrubs (more than 15 layering). The largest share of standard layering (more than $50 \%$ of all shoots) was observed in rootstocks B9, Malysh Budagovsky, 2-3-2, 2-3-8, 2-15-2, 2-9-94, 4-2-50, 9-1-9. In the rootstock collection, a correlation of 0.72 was established between the output of standard layering from the shrub and the average rooting score. The highest rooting of shoots in the mother plantation was in Malysh Budagovsky, 2-9-94, 2-15-2, 62-396 rootstocks, in which layering without roots amounted to no more than $5 \%$ of the total number.

\section{Conclusion}

Significant variability of the shoots' growth and development, as well as the degree of their rooting in 36 advanced and 4 standard rootstocks of the Michurinsk State Agrarian University selection was established. This is due to the genetic diversity of the studied genotypes collection of the genus Malus Mill., due to their different origin and use of the interspecific hybridization method. The greatest variability is characterized by the leaf surface area of the parent shrub.

We revealed correlations between the main morphological characters that are later planned to be used in the selection of potentially valuable hybrids. The relationship between the height of the parent shrub and the leaf surface area was noted: 0.71 per one shoot; 0.45 per the entire parent shrub; between the shrub's standard layering output and the average rooting score (at 0.72 ). 
The studies were carried out in the framework of the State task of the Ministry of Agriculture of the Russian Federation for 2020 on the topic: "Selection of winter-hardy dwarf clonal apple rootstocks using molecular markers and somatic tissue culture in vitro" (No. AAAA-A20-120011400199-6) based on the Collective Center "Selection of agricultural crops and production technology, storage and processing of food products for functional and therapeutic purposes" of the Michurinsk State Agrarian University.

\section{References}

1. V. I. Budagovsky, Karlikovye podvoi dlya yabloni [Dwarf rootstocks for apple trees] (Sel'khozgiz, Moscow, 1959)

2. N. M. Solomatin, Genofond vegetativno razmnozhaemyh form yabloni dlya uluchsheniya sortimenta podvoev, syr'evyh $i$ dekorativnyh sortov $v$ usloviyah CCHR [Gene pool of vegetatively propagated forms of apple trees for improving the assortment of rootstocks, raw materials and decorative varieties in the conditions of the Central Chernozemic Economic Region] (Moscow, 2018)

3. N. L. Churikova, Agrobiologicheskaya ocenka novyh klonovyh podvoev yabloni selekcii Michurinskogo GAU v usloviyah CCHR [Agrobiological assessment of new clonal stocks of apple trees of the selection of the Michurinsk SAU under conditions of the Central Chernozemic Economic Region] (Michurinsk State Agrarian University, Michurinsk, 2019)

4. O.I. Azarov, E.Z. Savin, L.G. Demenina, Bulletin of the Orenburg State University 1, 120 (2015)

5. E. Z. Savin, G. R. Mursalimova, Horticulture and Viticulture 4, 13 (2007)

6. I. V. Dubravina, Ispol'zovanie genofonda yabloni dlya sovershenstvovaniya sortov $i$ podvoev na yuge Rossii [Using the apple tree gene pool to improve varieties and rootstocks in southern Russia] (Kuban State Agrarian University, Krasnodar, 2014)

7. S. I. Isaev, M. V. Urazaeva, Scientific works of North Caucasian Federal Scientific Center of Horticulture, Viticulture, Wine-making 10, 91 (2016)

8. G. Fazio, H. Aldwinckle, T. Robinson, New York Fruit Quarterly 21, 25 (2013)

9. N. L. Russo, T. L. Robinson, G. Fazio, H. S. Aldwinckle, Plant Disease 92, 385 (2008)

10. D. Kviklys, N. Kviklienè, A. Bite, J. Lepsis, T. Univer, N. Univer, L. Buskienè, Horticultural Science 39, 1 (2012)

11. O. Melnyk, V. Goncharuk, V. Tsyrta, V. Osadchi, Proceedings of International Seminar "Apple rootstocks for intensive orchards", 75 (Warsaw-Ursynow, Poland, 1999)

12. R. V. Papikhin, N. M. Solomatin, D. Yu. Chestnikh, N. L. Churikova, Bulletin of the Michurinsk State Agrarian University 1-1, 50 (2012)

13. N. M. Solomatin, R. V. Papikhin, N. L. Churikova, I. M. Zueva, D. Yu. Chestnikh, L. V. Skorokhodova, Actual problems of the intensification of fruit growing in modern conditions, 130-133 (Samokhvalovichy, 2013)

14. M. L. Dubrovsky, R. V. Papikhin, Amazonia investiga 8, 688 (2019)

15. R. Papikhin, M. Dubrovsky, Advances in Intelligent Systems Research 167, 363 (2019)

16. A. Shlyavas, A. Trifonova, I. Shamshin, K. Boris, A. Kudryavtsev, XV EUCARPIA Fruit Breeding and Genetics Symposium-2019, 23 (2019)

17. Z. N. Tarova, N. L. Churikova, A. N. Gontyurev, V. A. Aksenova, Science and Education 1 (2019) 
18. Z. N. Tarova, N. L. Churikova, R. V. Papikhin, M. L. Dubrovsky, Bulletin of the Michurinsk State Agrarian University 3, 27 (2019)

19. E. N. Sedov, T. P. Ogoltsov, Programma i metodika sortoizucheniya plodovyh, yagodnyh i orekhoplodnyh kul'tur [Program and methodology of studies of fruit, berry and nut-fruit crops varieties], 608 (VNIISPK, Orel, 1999)

20. B. A. Dospekhov, Metodika polevogo opyta (s osnovami statisticheskoj. obrabotki rezul'tatov issledovanij) [Methods of field experience (with the basics of statistical processing of the results of the study)] (Agropromizdat, Moscow, 1985) 